\title{
Papers
}

\section{Systematic review of involving patients in the planning and development of health care}

\author{
Mike J Crawford, Deborah Rutter, Catherine Manley, Timothy Weaver, Kamaldeep Bhui, \\ Naomi Fulop, Peter Tyrer
}

\begin{abstract}
Objective To examine the effects of involving patients in the planning and development of health care. Data sources Published and grey literature. Study selection Systematic search for worldwide reports written in English between January 1966 and October 2000.

Data extraction Qualitative review of papers describing the effects of involving patients in the planning and development of health care.

Results Of 42 papers identified, 31 (74\%) were case studies. Papers often described changes to services that were attributed to involving patients, including attempts to make services more accessible and producing information leaflets for patients. Changes in the attitudes of organisations to involving patients and positive responses from patients who took part in initiatives were also reported.

Conclusions Evidence supports the notion that involving patients has contributed to changes in the provision of services across a range of different settings. An evidence base for the effects on use of services, quality of care, satisfaction, or health of patients does not exist.
\end{abstract}

\section{Introduction}

Over the past 20 years, governments throughout western Europe and North America have encouraged patients to contribute to the planning and development of health services. In England and Wales the involvement of patients is central to current efforts to improve the quality of health care. ${ }^{1}$ Underlying these changes is the belief that involving patients leads to more accessible and acceptable services and improves the health and quality of life of patients. ${ }^{2}{ }^{3}$ This view is endorsed by government policy, which states that involving patients leads to "more responsive services and better outcomes of care."4

Several authoritative guides to different ways to involve patients in the planning and development of services have been published. ${ }^{36}$ Involving patients is becoming less discretionary and more compulsory for the providers of services, but engaging patients is not an easy task, and no consensus on which methods are most effective under different circumstances exists. ${ }^{4} \mathrm{We}$ therefore carried out a literature review to examine the effects of involving patients and the circumstances in which these take place.

\section{Methods}

We identified papers for possible inclusion by combining searches of electronic databases, hand searches of reference lists of papers, contact with experts in the field and groups of patients belonging to the national Patients Forum, and a purposive hand search of grey literature held at the King's Fund and Department of Health libraries. Electronic databases searched comprised medical literature (Medline from 1966, Embase from 1988, PsychINFO from 1967), nursing literature (CINHAL from 1982), healthcare management literature (HMIC and HELMIS from 1983), and grey literature (EAGLE from 1980). We used medical subject headings and free text searches related to "user involvement"-combinations of "client," "consumer," "patient," "user" and "empowerment," "involvement," "participation," "representation;" for those related to planning and delivering health services-combinations of "health," "health care," "health services," "service," "welfare" and "delivery," "development," "organisational delivery," "organisational change," "organisational development," "planning," "provision." Searches were restricted to papers published in English between January 1966 and October 2000.

\section{Criteria for selection}

We included papers that described the involvement of patients, defined as "the active participation in the planning, monitoring, and development of health services of patients, patient representatives, and wider public as potential patients." ${ }^{36}$ We included all papers that described the effects of involving patients in the planning and development of health care. Excluded papers described patient involvement in other activities such as research, community development, health promotion, self management and self help, and the role of doctors and patients in determining individual treatment choices. We also excluded papers that described the measurement of patient satisfaction or patient preferences without describing how this information was used to help development of the service.

Two researchers (DR and CM) independently examined titles and abstracts of papers to decide if the
Department of Psychological Medicine, Imperial College School of Medicine, St Mary's Campus, London W2 1PD

Mike J Crawford senior lecturer in psychiatry Deborah Rutter research associate Catherine Manley research worker

Peter Tyrer professor of community psychiatry

Department of Social Science and Medicine, Division of Primary Care and Population Health Sciences, Imperial College Charing Cross Campus, London W6 8RP

Timothy Weaver research fellow

Institute of

Community Health Sciences, St Bartholomew's and the Royal London Medical School, London E1 2AD Kamaldeep Bhui senior lecturer in social and epidemiological psychiatry

Health Services Research Unit, London School of Hygiene and Tropical Medicine, London WC1E 7HT

Naomi Fulop senior lecturer in health services delivery and organisation research

Correspondence to: MJ Crawford m.crawford@ ic.ac.uk

bmj.com 2002;325:1263 
full text articles should be obtained. Where there was disagreement, this was resolved through consultation with a third reviewer (MJC). Full text articles were then examined and additional papers excluded if a more detailed examination showed that papers did not fit the study's aims.

\section{Qualitative analysis}

When reading articles for inclusion in the review each reviewer (DR, CM, or MJC) completed an annotation form. This allowed the reviewer to describe the nature of the evidence contained in the paper (quantitative research, qualitative research, review of previous literature, case study, expert opinion), the context of involvement (geographical setting, nature of the service, and patient group), the method used (for example, survey, patient representation at meetings), and finally whether or not outcomes of involvement were reported. Classifying papers in this way allowed us to develop a series of categories represented by keywords that were entered onto a bibliographic database and subsequently used to search for papers illustrating particular themes. An initial examination of findings showed that most papers that presented outcomes of involvement were case reports from workers involved in projects. Our approach to data analysis was therefore restricted to a narrative account of outcomes of involving patients and the nature of the evidence used to support these claims. ${ }^{7}$ Because no system for rating the quality of information in case reports exists, we could not assign quality ratings to the papers we included.

\section{Results}

We found 337 studies about involving patients in the planning and development of health care. Of these, we excluded $294(87 \%)$ because they did not describe the effects of involvement.

Accepted studies included 42 papers (12\%) that described the effects of 40 initiatives involving patients (table 1). Of these, 31 were case reports, five were the results of surveys, three examined records of meetings, and three described the findings of action research. Four reports clearly described the use of qualitative research methods. We did not find any reports that used comparative or experimental research methods. Papers described a range of different models of involvement applied in a range of settings in hospitals and the community. The different effects of involving patients and the nature of the evidence to support these findings are summarised in table 2. We were unable to identify any reports that investigated the effects of involving patients on the health, quality of life, or satisfaction of those using services.

\section{Effects on users involved}

Several papers commented that patients who participated in initiatives welcomed the opportunity to be involved and that their self esteem improved as a result of their contributions. ${ }^{8-14}$ The findings of surveys and interviews with patients are in support. ${ }^{15} 16$ We also identified reports in which patients described dissatisfaction with the process. ${ }^{17} 18$ Several studies commented that staff involved in initiatives found the experience rewarding, ${ }^{9}{ }^{19}{ }^{20}$ but others describe difficult relationships between patients and staff. ${ }^{21}$

\section{Changes to services}

Among the most frequently reported effects of involving patients was the production of new or improved sources of information for patients. ${ }^{82-30}$ Other changes included efforts to make services more accessible through simplifying appointment procedures, ${ }^{26}{ }^{30-32}$ extending opening times, ${ }^{24} 291$ improving transport to treatment units, ${ }^{1523} 26$ and improving access for people with disabilities. ${ }^{8} 26$

Several reports describe new services being commissioned as a result of the requests of patients, including advocacy, ${ }^{24}{ }^{27}$ initiatives aimed at improving opportunities for employment, ${ }^{1524}$ complementary medicine, ${ }^{23}$ crisis services, ${ }^{16}$ and fertility treatments. ${ }^{32}$ Two reports describe how involving patients led to proposals to close hospitals being modified or abandoned. ${ }^{33} 34$

\section{Other effects of patients being involved}

Eight reports state that initiatives had a more general effect on organisational attitudes to involving patients. These included comments that staff attitudes to involving patients became more favourable ${ }^{8161935}$ and that the culture of organisations changed in a way that made them more open to involving patients. ${ }^{27}{ }^{35}$ Some projects resulted in further initiatives aimed at strengthening the involvement of patients. ${ }^{37}$ Concerns were also expressed by researchers who found evidence that involving patients was used to legitimise decisions that would have been made whether or not patients supported them. ${ }^{19}{ }^{38-40}$ One report concluded that the decision making process was slower because patients were involved..$^{18}$

\section{Overall impact of involvement}

Attempts to gauge the overall impact of involving patients have been made by conducting surveys of participants and retrospectively examining records of meetings. A survey of the leaders of public involvement initiatives of Health Systems Agencies in the United States in 1980 asked respondents to judge the effects of involving patients. ${ }^{42}$ Of the $154(76 \%)$ who replied, $75 \%$ (116) said that involving patients had improved the quality of health services and $46 \%$ (71) that it had led to improvements in people's health. Of 63 patient participation groups in primary care settings surveyed in Britain in the mid-1980s, $32(52 \%)$ were able to provide details of at least one change that groups had initiated. ${ }^{31}$

Facilitated meetings between workers in primary care and patients with diabetes in 17 primary care centres in Stockholm in the mid-1980s generated 196 plans for improving patient care. Eighteen months later the extent to which plans had been implemented was evaluated: $70 \%$ (137) of plans had been implemented. ${ }^{29}$ A retrospective examination of records from meetings of five mental health forums in Kent, United Kingdom, identified 57 concerns raised by groups over a two year period. ${ }^{43}$ Of these, 22 (39\%) resulted in a response from providers of services that was judged acceptable.

\section{Discussion}

A review of more than 300 papers on involving patients in the planning and development of health care found that few described the effects of this 
Table 1 Reports providing details of the effects of involving patients in planning and delivering health care

\begin{tabular}{|c|c|c|c|c|c|}
\hline Study & Nature of evidence & Form of involvement & Nature of service & Location & Reported outcomes \\
\hline Carlson and Rosenqvist ${ }^{29}$ & Retrospective review of records & Consultation meetings with 34 patients & Diabetes management in primary care & Sweden & $\begin{array}{l}\text { Changes to organisation of care and } \\
\text { information for patients }\end{array}$ \\
\hline Milewa $^{43}$ & Retrospective review of records & Five patient forums & Mental health & UK & $\begin{array}{l}\text { Unspecified changes to organisation and } \\
\text { delivery of services }\end{array}$ \\
\hline Pilgrim and Waldron ${ }^{24}$ & Action research & Patient group with 14 members & Mental health & UK & $\begin{array}{l}\text { Extension of community mental health } \\
\text { team hours; advocate funded; service } \\
\text { information for users published }\end{array}$ \\
\hline Sheppard $^{9}$ & Action research qualitative methods & $\begin{array}{l}\text { Meetings with patients at five general } \\
\text { practitioners' practices }\end{array}$ & Primary care & UK & $\begin{array}{l}\text { User involvement appreciated by } \\
\text { patients and providers }\end{array}$ \\
\hline Taylor $^{40}$ & Action research & $\begin{array}{l}\text { Range of consultation projects across } \\
\text { all sectors and stakeholders }\end{array}$ & Learning disability & UK & $\begin{array}{l}\text { Implementation of revised patient } \\
\text { information; patients' input into } \\
\text { substantial overhaul of services }\end{array}$ \\
\hline Bowl $^{17}$ & $\begin{array}{l}\text { Telephone survey of } 31 \text { managers; } \\
\text { case studies }\end{array}$ & Patient forums & Mental health & UK & Patient dissatisfaction \\
\hline Checkoway et a $\mathrm{l}^{41}$ Checkoway $^{42}$ & Survey of 154 service providers & Patient representation at meetings & General health & USA & $\begin{array}{l}\text { Increased confidence of users who } \\
\text { participate; changes to services provided }\end{array}$ \\
\hline Hendessi $i^{8}$ & Survey of service providers & $\begin{array}{l}\text { London based patient groups and } \\
\text { forums }\end{array}$ & Broad range & UK & $\begin{array}{l}\text { Changes in policy, quality and methods } \\
\text { of service delivery }\end{array}$ \\
\hline $\mathrm{NHSE}^{32}$ & Survey of service providers & Mixed involvement initiatives & Range of settings & UK & $\begin{array}{l}\text { Simplified procedures; provision of new } \\
\text { services }\end{array}$ \\
\hline Todd et al ${ }^{18}$ & Interviews, qualitative analysis & $\begin{array}{l}\text { Patient and carer representation on } \\
\text { planning boards }\end{array}$ & Learning disability services & UK & User and carer dissatisfaction \\
\hline Atkinson and Farshi ${ }^{51}$ & Case study & $\begin{array}{l}\text { Audit involving interviews with } 32 \\
\text { service users }\end{array}$ & Community paediatric & UK & Changes to dissemination of information \\
\hline Barnes $^{13}$ & Case studies & Three user groups & Mental health & UK & Improved self esteem \\
\hline Barnes $^{52}$ & Case study & User committee & Community care for physically disabled & UK & No changes implemented \\
\hline Berger et al ${ }^{12}$ & Case study & Consumer committee & HIV clinic & Australia & $\begin{array}{l}\text { Patient friendly services and support; } \\
\text { improved self esteem of patients }\end{array}$ \\
\hline Broderick $^{33}$ & Case study & Survey of 140 people by $\mathrm{CHC}$ & General health & UK & Reversal of plan to close hospital \\
\hline Dixon et al ${ }^{53}$ & Case study & $\begin{array}{l}\text { Two patients employed as consumer } \\
\text { advocates in assertive outreach team }\end{array}$ & Mental health & USA & $\begin{array}{l}\text { Improved engagement with patients and } \\
\text { staff awareness, but problems with } \\
\text { boundaries }\end{array}$ \\
\hline Elizabeth $^{14}$ & Case studies & Three citizens' juries & General health & UK & $\begin{array}{l}\text { Increase in participants' self confidence } \\
\text { and interest in local democracy }\end{array}$ \\
\hline Gummer and Furney ${ }^{27}$ & Case study & $\begin{array}{l}\text { Staff-patient forum: patients represent } \\
\text { six groups }\end{array}$ & Mental health & UK & $\begin{array}{l}\text { Improved design of new services; plan } \\
\text { for advocacy; improved information, } \\
\text { training and recruitment; culture shift; } \\
\text { increased user self esteem }\end{array}$ \\
\hline Heginbotham ${ }^{34}$ & Case studies & $\begin{array}{l}\text { Range of initiatives including campaign } \\
\text { by CHCs }\end{array}$ & Broad range & UK & Reversal of plan to close hospital \\
\hline Kirk et a ${ }^{38}$ & Case studies & $\begin{array}{l}\text { Range of initiatives including interviews } \\
\text { with service users }\end{array}$ & Primary care & UK & $\begin{array}{l}\text { Supported existing plans for expansion } \\
\text { of services }\end{array}$ \\
\hline Lord et a ${ }^{16}$ & Case study with qualitative methods & $\begin{array}{l}\text { Stakeholder meetings including service } \\
\text { users }\end{array}$ & Mental health & Canada & $\begin{array}{l}\text { Shift in service delivery toward } \\
\text { individualised care; broader based } \\
\text { ownership and control }\end{array}$ \\
\hline Millet $^{28}$ & Case studies & $\begin{array}{l}\text { Survey of } 120 \text { patients and three focus } \\
\text { groups }\end{array}$ & Medical outpatients & UK & $\begin{array}{l}\text { Development of information and shared } \\
\text { care record book }\end{array}$ \\
\hline NHS Executive $e^{25}$ & Case studies & Mixed methods (surveys, meetings) & General health & UK & $\begin{array}{l}\text { Impact on strategies unclear; some } \\
\text { service improvements, better } \\
\text { communication with local residents }\end{array}$ \\
\hline Pagett $^{26}$ & Case study & Service users panel & Medical outpatients & UK & $\begin{array}{l}\text { Patient information and appointment } \\
\text { cards revised; disabled facilities } \\
\text { improved }\end{array}$ \\
\hline Pecarchik et al ${ }^{54}$ & Case study & Health and welfare council & General health care & USA & $\begin{array}{l}\text { Pressure from service users speeded up } \\
\text { changes to organisation of blood banks }\end{array}$ \\
\hline Poole 20 & Case study & User focused monitoring & Neurological disorder & UK & $\begin{array}{l}\text { Patients and staff found user } \\
\text { involvement rewarding }\end{array}$ \\
\hline Sheahan ${ }^{55}$ & Case study & Survey of discharged patients & General hospital care & Australia & Development of information booklet \\
\hline Silva ${ }^{11}$ & Case study & Client group to plan respite facility & Mental health & USA & $\begin{array}{l}\text { Clients directed service design; became } \\
\text { volunteer staff; reduced dependency }\end{array}$ \\
\hline Smith $^{10}$ & Case study & $\begin{array}{l}\text { Ex-client representation at meetings, } \\
\text { survey of current clients }\end{array}$ & Mental health & USA & $\begin{array}{l}\text { Promotion of rehabilitation through } \\
\text { enhanced self worth, self reliance }\end{array}$ \\
\hline Summers and McKeown ${ }^{19} \dagger$ & Case study & $\begin{array}{l}\text { Mixed: focus groups, consultation, } \\
\text { interviews, patient survey, and CHC }\end{array}$ & Maternity services & UK & $\begin{array}{l}\text { Strategy reflects call for more } \\
\text { linkworkers; better catering; staff } \\
\text { interest in user views stimulated }\end{array}$ \\
\hline Summers and McKeown ${ }^{19} \dagger$ & Case study & $\begin{array}{l}\text { Mixed: focus groups, user forum, } \\
\text { survey of voluntary organisations, and } \\
\mathrm{CHC}\end{array}$ & Mental health & UK & $\begin{array}{l}\text { Improved self esteem for users; staff } \\
\text { interest in user views stimulated }\end{array}$ \\
\hline Tishler $^{56}$ & Case study & $\begin{array}{l}\text { Consumer board overseeing service } \\
\text { providers }\end{array}$ & Mental health & USA & Training for staff on patient needs \\
\hline Williams $\mathrm{s}^{30}$ & Case study & Patient and staff interviews; survey & Outpatient services & UK & $\begin{array}{l}\text { Waiting times, notes retrieval, patient } \\
\text { information, and feedback to patients } \\
\text { improved }\end{array}$ \\
\hline $\begin{array}{l}\text { Wistow and Barnes, }{ }^{15} \text { Barnes and } \\
\text { Wistow } \\
\text { Wistow }{ }^{36} \text { and Barnes and }\end{array}$ & Case study with qualitative methods & Survey, citizen advocacy, meetings & Community health and social care & UK & $\begin{array}{l}\text { Improved access to services; enhanced } \\
\text { self esteem of users who participated; } \\
\text { service provider became more open to } \\
\text { user involvement }\end{array}$ \\
\hline Woods ${ }^{23}$ & Case study & Questionnaire survey & Surgical inpatient & UK & $\begin{array}{l}\text { Revised admissions and discharge } \\
\text { procedures and information; improved } \\
\text { ancillary services; complementary } \\
\text { medicine; liaison group established }\end{array}$ \\
\hline Young $^{21}$ & Case study & $\begin{array}{l}\text { Lay board of directors controlling a } \\
\text { primary care clinic }\end{array}$ & Primary care & Canada & Dissatisfaction among service providers \\
\hline
\end{tabular}

$\mathrm{CHC}=$ Community Health Council. primary care clinic

${ }^{*} \mathrm{~A}$ form of quality assessment by service users. †Two separate case studies in one report. 
process. Those that have done so are generally case studies where project administrators running projects have commented on what the project achieved. Although these reports support the view that involving patients has contributed to changes to services, the effects of involvement on accessibility and acceptability of services or impact on the satisfaction, health, or quality of life of patients has not been examined.

We found some of the most informative material for this review in grey literature. While we made considerable effort to locate grey literature, the methods we used would not have identified all reports on this subject, especially those from outside the United Kingdom. Another potential problem in interpreting the results is that publication bias may favour the publication of reports from initiatives that were judged to be successful.

Several factors may account for our central finding, the limited amount of information about the effects of involving patients. The aims of involving patients have always been broader than just improving the quality of health care. Involving patients has been viewed by many as a democratic or ethical requirement: because patients pay for services they have a right to influence how they are managed. ${ }^{45}{ }^{45}$ An alternative view is that involving patients is not intended to devolve power to patients but to legitimise the decisions of policy makers and administrators. ${ }^{46}$ It is argued that through consulting with users of health services, support for decisions that would otherwise be unpopular can be obtained. ${ }^{47}$ Such aims imply that establishing mechanisms for involving patients should be seen as an end in itself rather than as a means of improving the quality of services. However, initiatives that fall short of bringing about changes to services are not in keeping with the aims of current policy or patients.

The effects of involving patients are likely to be complex, affecting different aspects of services in different ways. The views of patients are among many factors that influence change in health services, and providers of health care remain the final arbiter of how much weight is attached to patients' views. ${ }^{14}$ Separating out change specifically attributable to the participation of patients is a difficult task. ${ }^{48}$ Despite these problems, possible effects, amenable to formal evaluation, of involving patients have been discussed, including extent of use of the service, satisfaction, and quality of life. ${ }^{2}$ Patients' involvement is not without its costs, ${ }^{49}$ and including outcome measures in future evaluations of involving patients could enable comparisons of different approaches and evaluation of the effects of suggestions made by patients.

Table 2 Nature of evidence supporting effects of involvement of patients in planning and delivering health care

\begin{tabular}{|c|c|c|c|}
\hline Effect & $\begin{array}{l}\text { Quantitative research } \\
\text { (observational or } \\
\text { experimental studies) }\end{array}$ & $\begin{array}{c}\text { Qualitative } \\
\text { research }\end{array}$ & Case studies \\
\hline Positive effects on patients who participate & $x$ & $\mathrm{v}$ & $\mathrm{v}$ \\
\hline Negative effects on patients who participate & $x$ & $\checkmark$ & $\checkmark$ \\
\hline Changes to information given to patients & $x$ & $x$ & $\mathrm{~V}$ \\
\hline Changes to existing services & $x$ & $v$ & $\mathrm{v}$ \\
\hline Development of new services & $x$ & $\checkmark$ & $\checkmark$ \\
\hline Increased use of services & $x$ & $x$ & $x$ \\
\hline Increased satisfaction among patients & $x$ & $x$ & $x$ \\
\hline Improved health or quality of life for patients & $x$ & $x$ & $x$ \\
\hline
\end{tabular}

What is already known on this topic

Involving patients in planning and delivering health services is recommended as a means of improving the quality of services

Methods for engaging with patients have been considered in depth, but the effects of involving patients are less clear

\section{What this study adds}

Few studies have explored the effects of involving patients

Involving patients has contributed to changes in service provision, but the effects of these on quality of care have not been reported

\section{Conclusions}

Patients have contributed to the planning and development of services across a range of settings, but the effects of this process on the quality and effectiveness of services are unknown. This absence of evidence should not be mistaken for an absence of effect. Healthcare providers may be increasingly required to demonstrate that they involve patients in the planning process, but they will also continue to be accountable for the decisions they make. A better evidence base may be necessary to persuade providers to place greater emphasis on patients' views when making decisions about services.

We thank members of a steering group that oversaw the project, groups from the Patients Forum and others who responded to our request for grey literature, and staff at the Department of Health, Kings Fund, and Imperial College for their help in identifying grey literature.

Contributors: MC, TW, KB, NF, and PT conceived the study. MC, $\mathrm{DR}$, and $\mathrm{CM}$ collected and analysed data. MC, DR, CM, TW, KB, $\mathrm{NF}$, and PT contributed to analysing data, interpreting the results, and writing the paper. $\mathrm{MC}$ is the guarantor.

Funding: The project was funded by a grant from London Region NHS Executive, Organisation and Management Research and Development Programme.

Competing interests: None declared.

1 NHS Executive. The NHS plan: a plan for investment, a plan for reform. London: Department of Health, 2000

2 Beresford P, Croft S. Citizen involvement: a practical guide for change. Basingstoke: Macmillan, 1993.

3 Barker J, Bullen M, de Ville J. Reference manual for public involvement. Bromley, West Kent, Lambeth, Southwark, and Lewisham Health Authorities, 1997.

4 NHS Executive. Patient and public involvement in the new NHS. Leeds: Department of Health, 1999.

5 McIver S. Obtaining the views of users of health services. London: King's Fund, 1991.

6 Kelson M. User involvement: A guide to developing effective user involvement strategies in the NHS. London: College of Health, 1997.

7 Fulop N, Allen P, Clark A, Black N. Studying the organisation and delivery of health services: research methods. London: Routledge, 2001

8 Hendessi M. Getting better all the time? A report of a project on user and carer involvement in the NHS. London: Greater London Association of Community Health Councils, 1994.

9 Sheppard, B. A voice for older Londoners in the doctor's surgery. London: Age Concern, 2000.

10 Smith MK. Client involvement in psychosocial rehabilitation. Psychosoc Rehabil J $1984 ; 8: 35-43$.

11 Silva EL. Collaboration between providers and client-consumers in public mental health programs. New Dir Ment Health Serv 1990;46:57-63.

12 Berger E, Carter A, Casey D, Litchefield L. What's happening with consumer participation? [Consumer note.] Aust N Z J Ment Health Nurs 1996;5:131-5.

13 Barnes M. From passive recipient to active citizen: participation in mental health user groups. J Ment Health 1997;6:289-300.

14 Elizabeth S. Citizens' juries: outcomes of an experiment in citizenship and health. Health Care Risk Rep.1998;4:16-17. 
15 Wistow G, Barnes M. User involvement in community care: origins, purposes and applications. Public Adm 1993;71:279-99.

16 Lord J, Ochocka J, Czarny W, MacGillivary H. Analysis of change within a mental health organization: a participatory process. Psychiatr Rehabil 1998;21:327-39.

17 Bowl R. Legislating for user involvement in the. United Kingdom: Mental health services and the NHS and Community Care Act 1990. Int J Soc Psychiatry 1996;42:165-80.

18 Todd S, Felce D, Beyer S, Shearn J, Perry J, Kilsby M. Strategic planning and progress under the all Wales strategy: reflecting the perceptions of stakeholders. J Intellect Disabil Res 2000;44:31-44.

19 Summers A, McKeown K. Local voices: evolving a realistic strategy on public consultation. Public Health 1996;110:145-50.

20 Poole B. Success all round. MS Matters 2000;34:14-5.

21 Young TK. Lay-professional conflict in a Canadian community health center: a case report. Med Care 1975;13:897-904.

22 NHS Executive. Patient partnership: building a collaborative strategy London: Department of Health, 1996.

23 Woods T. The use of ward forums in obtaining patient feedback CCUFLINK. 1994;4:7-8

24 Pilgrim D, Waldron L. User involvement in. mental health service development: how far can it go? J Ment Health 1998;7:95-104.

25 NHS Executive. Involving local people: examples of good practice. Leeds: Department of Health, 1994

26 Pagett J. Listening to user views: an out patient user panel in Llanelli and Dinefwr NHS Trust. CCUFLINK 1994;4:9.

27 Gummer T, Furney S. The business of listening. Health Manag $1998 ; 2: 12-3$

28 Millett A. Patient participation in service improvement: the initial measures project experience. Health Expect 1999;2:280-4

29 Carlson A, Rosenqvist U. Locally developed plants for quality diabete care: Worker and consumer participation in the public healthcare system. Health Educ Res 1990;5:41-52

30 Williams D. Improving the quality of service in the out-patient department at Singleton Hospital. CCUFLINK 1994;4:10-2.

31 Richardson A, Bray C. Promoting health through participation: experience of groups for patient participation in general practice. London: Policy Studie Institute, 1987.

32 NHS Executive. Patient partnership. London, NHS Executive, 1998.

33 Broderick C. Partners for change. Health Director 1997;1:14-5.

34 Heginbotham C. Listening to local voices. Birmingham: Nationa Association of Health Authorities and Trusts, 1993.

35 Barnes M, Wistow G. Researching user involvement. Leeds: Nuffield Institute for Health Service Studies, 1992

36 Barnes M, Wistow G. Learning to hear voices: Listening to users of mental health services J Ment Health 1994:3:525-40.

37 Harris B. The Islington Mental Health Forum: A case study in how to get users involved. London, Good Practices in Mental Health, 1989

38 Kirk S, Bailey J, Glendinning C, Burkey Y. Involving communities in health service planning in primary care. Health Soc Care Community $1997 ; 5: 398-407$
39 Harrison S, Mort M. Which champions, which people? Public and use involvement in health care as a technology of legitimation. Soc Policy Adn 1998;32:60-70.

40 Taylor P. Over the border: Swindon's consumer involvement project. CCUFLINK 1994;4:19-20.

41 Checkoway B, Thomas B, O'Rourke TW, Bull D. Correlates of consume participation in health planning agencies: findings and implications from a national survey. Policy Stud Rev 1984;3:296-310.

42 Checkoway B. Public participation in health planning agencies: promise and practice. J Health Polit Policy Law 1982;7:723-33.

43 Milewa T. Community participation and health care priorities: reflections on policy, theatre and reality in Britain. Health Promotions International 1997;12:161-7.

44 Pritchard P. Partnership with patients. London: Royal College of General Practitioners, 1993.

45 Barnes M. Public expectations: from paternalism to partnership. Changing relationships in health and health services. London: Nuffield Trust and University of Cambridge, 1999

46 White D. Consumer and community participation: a reassessment of process, impact and value. In: Albrecht G, Fitzpatrick R, Scrimshaw SC, eds. Handbook of social studies in health and medicine. London: Sage, 2000:465-80.

47 Donovan J, Coast J. Public participation in priority setting: commitment or illusion. In: Coast J, Donovan J, Frankel S, eds. Priority setting: the health care debate, Chichester: Wiley, 1996.

48 Smith, H. Collaboration for change:partnership between service users, planners, and managers of mental health services. London: Kings Fund, 1988.

49 Cooper TL. The hidden price tag: participation costs and health planning. Am J Public Health 1979;69:368-74.

50 Nutt PC. The merits of using experts or consumers as members of planning groups: a field experiment in health planning. Acad Manag $J$ 1976;19:378-94

51 Atkinson K, Farshi Z. Focus on patient/user involvement: a multidisciplinary project leads to significant changes in practice. Audit Trends 1998;6:24-6.

52 Barnes C. Participation and control in day centers for young disabled people aged 16 to 30 years. In: Swain J, Finklestein V, eds. Disabling barr ers, enabling environments, Milton Keynes: Open University Press, 1993.

53 Dixon L, Krauss N, Lehman A, Fox L, Hilton D, Solomon P. Consumers as service providers: the promise and challenge. Community Ment Health J 1994;30:615-34

54 Pecarchik R, Ricci E, Belson B Jr. Potential contribution of consumers to an integrated health care system. Public Health Rep. 1976;91:72-6.

55 Sheahan M. Customer focus: patient organisation and EQuIP in collaboration. J Ouality Clin Pract.1999;19:139-144.

56 Tischler GL. The effects of consumer control on the delivery of services Am J Orthopsychiatry 1971;41:501-5.

(Accepted 30 May 2002) 